\title{
Effect of Carbon Content and Microstructure on the Diffusion of Hydrogen in Low Carbon Steels
}

\author{
J. G. Arenas-Salcedo, J. G. Godínez-Salcedo*, J. L. González-Velázquez, J. M. Medina-Huerta \\ Instituto Politécnico Nacional, Escuela Superior de Ingeniería Metalúrgica, Departamento de \\ Ingeniería Metalúrgica y Materiales, México \\ *E-mail: drgodinez@ hotmail.com
}

doi: $10.20964 / 2020.11 .39$

Received: 24 April 2020 / Accepted: 24 July 2020 / Published: 30 September 2020

In this work, the electrochemical permeation technique proposed in the ASTM-G148-97 Ed 2011 standard was used to determine the maximum oxidation current density, $i_{\text {max }}$; breakthrough time; $t_{b}$, effective hydrogen diffusion coefficient, $D_{e f f}$, and surface hydrogen concentration, $\boldsymbol{C}_{\boldsymbol{H}}^{0}$, for several API 5L steels. The results show that steels with a carbon content of less than or equal to $0.052 \%$ wt and a ferritic-bainitic microstructure have higher $D_{\text {eff }}$ and $i_{\max }$ values than steels with a higher carbon content

and a ferritic-pearlitic microstructure, while the $\boldsymbol{C}_{\boldsymbol{H}}^{0}$ and tb parameters show a clear tendency to decrease when the microstructure changes from ferritic-pearlitic to ferritic-bainitic. The $D_{\text {eff }}$ values obtained in this work are consistent with published data, both in terms of their magnitude and in relation to the effects of carbon content and microstructure.

Keywords: hydrogen diffusion, diffusion equations, Electrochemical Permeation Technique.

\section{FULL TEXT}

(C) 2020 The Authors. Published by ESG (www.electrochemsci.org). This article is an open access article distributed under the terms and conditions of the Creative Commons Attribution license (http://creativecommons.org/licenses/by/4.0/). 